\title{
The presence of Syphacia obvelata in laboratory mice (BALB/c) - parasite antigens in immune response
}

\author{
A. PEREC, A. OKULEWICZ
}

Department of Parasitology, Institute of Genetics and Microbiology, University of Wroclaw, Przybyszewskiego 63, 51-148 Wrocław, Poland; E-mail:agap@microb.uni.wroc.pl

\begin{abstract}
Summary
In conventional mice colonies, mouse pinworm, Syphacia obvelata is found very often. Several studies indicate that infection with this parasite can modulate the immune system of the host and can affect experimental final results. The aim of our study was to investigate the most immunogenic proteins of $S$. obvelata inducing both local and systemic immune response in naturally infected laboratory mice. Protein extracts of $S$. obvelata were analysed by Western blotting to examine their antigenic character. The antigens were probed with serum and mucosa of $S$. obvelata naturally infected mice. Surface and somatic antigens were recognized by serum and mucosal $\operatorname{IgG}, \operatorname{IgA}$ and $\operatorname{IgM}$ antibodies. The most immunogenic and dominant proteins were observed. Proteins of $\mathrm{Mw} \sim 70,65$ and $48 \mathrm{kDa}$ showed the most evident reaction with serum and mucosa antibodies of infected animals. Surface and somatic antigens of nematode $S$. obvelata eliciting immune response in laboratory mice may be useful in development of a diagnostic test which could be applied for the infection control prior the experiments.
\end{abstract}

Key words: Syphacia obvelata; pinworms; laboratory mice; immune response

\section{Introduction}

In biological and biomedical research, where obtaining of reliable and reproductible results is very important, the use of living laboratory animal models is still necessary. The environments of laboratory animals are standardised in order to reduce variation in results, especially in studies performed during the development and registration pharmaceutical products and chemicals. Still little is known about the effects of environmental changes on the biological variation in experimental results (Baumans, 1998) as well as laboratory mice are seldom investigated for autochthonous ecto and endoparasites prior their use in the experiments (Pinto et al., 1994, 2001). The control or eradication of worm burdens in laboratory animals ensures the proper procedures in scientific research. In colonies of conventional mice, mouse pinworm, Syphacia obvelata is found very often (Pacoń \& Piekarska, 2004). It has been reported that sensitivity and accuracy of results may be compromised when infections agents are present in the colonies (Gilioli et al., 2000). Also, studies carried out by Sato et al. (1995) indicate that infection can modulate the immune system of the host and affect experimental final results (Pinto et al., 1994; Bazzano et al., 2002).

Syphacia obvelata is an intestinal nematode belonging to the family Oxyuridae, which comprise the largest group of helminth parasites of laboratory animals. This is a small, white, cylindrical worm found in the caecum and colon of mice, sporadically occurring also in rats and hamsters. The life cycle is simple and direct (Dick \& Wright, 1973). The host becomes infected by ingesting eggs directly from the perianal region of an infected animal, or indirectly from contaminated water and food. Retroinfection may possibly occur (Taffs, 1976). According to research of Bazzano et al. (2002) the frequency of $S$. obvelata in laboratory animals ranged from $9 \%$ to $74 \%$ and the intensity of infection was from 13 to 67 specimens. In the present study carried out by us the prevalence of infection was as high as $66 \%$ however the intensity ranged from 1 to 250 specimens. According to Taffs (1976) the prevalence of $S$. obvelata infection in laboratory animals may be a function of: age (the intensity decreases with an increasing age), sex (higher prevalence in male hamsters than females), strain and the host status. Our previous examinations of 176 laboratory mice (BALB/c strain) demonstrated that the prevalence of infection in males was $70 \%$ (with the intensity of infection of $1-102$ ) and in females was $52 \%$ (with the intensity of infection of $1-34$ individuals) (Okulewicz \& Perec, 2003).

During the infection the host is exposed to parasite-derived 
antigens which can be recognized by the immune system. These are usually proteins, glycoproteins and carbohydrates which are located on the parasite surface or excretory/ secretory products. Some antigens elicit humoral and cellular immune responses both local and systemic (Wędrychowicz, 1997; Kołodyński \& Okulewicz, 1998). Detection and recognition of nematode antigens increases with the development of specific immunodiagnostic methods and help to understand protective mechanisms of the hosts which are elicited during infection. The knowledge of these protective antigens becomes useful in development of diagnostic tests and production of medicaments and vaccines.

The aim of our study was to investigate the most immunogenic proteins of $S$. obvelata inducing both local and systemic immune response in naturally infected BALB/c mice.

\section{Materials and Methods}

\section{Host and parasite}

120 laboratory mice (Mus musculus) of BALB/c strain, 2 4 months old, both sexes with natural infection of $S$. obve$l a t a$, were used during the experiment. They came from the conventional colony of Institute of Genetics and Microbiology. Adults $S$. obvelata were harvested from the colon and caecum after sacrifice of the mice. All animal procedures were approved by the University of Wroclaw and Local Committee of Ethics.

\section{Serum and mucosa collection}

During postmortem, serum and intestinal mucosa samples were obtained for Western blot analysis (20 samples) - (De Vos et al., 1992). Uninfected mice provided controls. Collected serum and mucosa samples were individually stored at $-40^{\circ} \mathrm{C}$.

\section{Isolation of surface proteins of S. obvelata}

Collected nematodes were purified in PBS (pH 7.4) for $6-$ $9 \mathrm{~h}$ and then washed 10 times in $0.15 \mathrm{M} \mathrm{NaCl}$. The worms (at a concentration of $9 \times 10^{2}$ adults per $\mathrm{ml}$ ) were next suspended in $0.05 \mathrm{M}$ carbonate/bicarbonate buffer $(\mathrm{pH} 8.2)$ and incubated with $0.3 \mathrm{mg} / \mathrm{ml}$ of sulfosuccinimidyl-2(biotinamido)ethyl-1,3ditiopropioniate (NHS-SS-biotin Sigma) for $1 \mathrm{~h}$ at room temperature in the dark. Biotinylation was terminated by washing extensively in $0.15 \mathrm{M}$ $\mathrm{NaCl}$. Then pinworms were homogenised and extracted in Tris-buffered-saline (TBS, $0.15 \mathrm{M} \mathrm{NaCl}$ in $10 \mathrm{mM}$ Tris, $\mathrm{pH}$ 7.4) containing protease inhibitors (0.2 M Tris, $0.15 \mathrm{M}$ $\mathrm{NaCl}, 0.02 \mathrm{M}$ EDTA, $13.5 \mu \mathrm{M}$ TLCK, $7.0 \mu \mathrm{M}$ TPCK, 0.5 $\mu \mathrm{M}$ PMSF and $2 \mu \mathrm{M}$ of antypain) in an ice-water bath. The homogenate was extracted overnight at $4^{\circ} \mathrm{C}$ then centrifuged at $16000 \mathrm{~g}, 30 \mathrm{~min}, 4^{\circ} \mathrm{C}-\mathrm{TBS}$ extract (AP1 fraction). The pellet was resuspended in $500 \mu \mathrm{l}$ TBS containing $1 \%$ SDS and boiled for $5 \mathrm{~min}$. The mixture was than recentrifuged for $30 \mathrm{~min}$ at $16000 \mathrm{~g}$, the supernatant was removed (AP2 fraction) and the pellet was resuspended in $500 \mu \mathrm{l}$ TBS with $5 \%$ 2-mercaptoethanol to obtain AP3 fraction
(Keith et al., 1990; Wędrychowicz et al., 1994). The extracts were frozen at $-20^{\circ} \mathrm{C}$.

\section{Isolation of somatic proteins of S. obvelata}

After 3 washings in Tris- $\mathrm{HCl}$ buffer $(0.05 \mathrm{M}, \mathrm{pH} 8.0)$ containing $0.2 \mathrm{M} \mathrm{NaCl}$ and $1.0 \%$ Triton $\mathrm{X}-100$, adult worms at a concentration of $5 \times 10^{2} / \mathrm{ml}$ were homogenized in a glass homogenizer on ice (AS fraction). Insoluble fragments were removed by centrifugation $\left(25000 \mathrm{~g}, 4^{\circ} \mathrm{C}\right)$ and the clear supernatant fraction was frozen at $-20^{\circ} \mathrm{C}$ (De Graaf et al., 1996).

\section{Gel electrophoresis}

Solubized surface and somatic extracts (at a concentration of $20-30 \mu \mathrm{g} / \mathrm{ml}$ ) were analyzed on SDS - polyacrylamide gels comprised of a $6 \%$ stack and $12 \%$ resolving gel using the discontinuous buffer system of Laemmli (1970).

\section{Western blot analysis}

Western blotting was carried out following established protocols of Towbin et al. (1979). Polypeptides were transferred onto nitrocellulose membranes using $25 \mathrm{mM}$ Tris $\mathrm{HCl}$ (pH 8.3), $192 \mathrm{mM}$ glycine, $20 \%$ methanol. The blotting was carried out for $3 \mathrm{~h}$ at $60 \mathrm{~V}, 0.22 \mathrm{~A}$. The membrane was blocked with $3 \% \mathrm{BSA}$ in PBS for $12 \mathrm{~h}$ in $4^{\circ} \mathrm{C}$. After rinsing briefly in $0.3 \%$ milk - TBS the membrane was incubated with test and control serum - at 1:50 dilution and abomasal mucosa - at 1:20 dilution in blocking buffer, for $1 \mathrm{~h}$ at room temperature and then washed $4 \mathrm{x}$ over a period of $10 \mathrm{~min}$ each time. The membrane was then incubated with HRP - conjugated anti - mice IgG (at 1:500 dilution) and anti - mice IgA and IgM (at 1:200 dilution) for serum and anti-mice IgG (at 1:500 dilution) and anti - mice IgA (at 1:100 dilution) for mucosa (Sigma). The membrane was incubated for $1 \mathrm{~h}$ at room temperature and washed 4 times for $10 \mathrm{~min}$ in $0.3 \%$ milk - TBS. After washing the blots were developed and bound antibodies were visualized by adding 4-chloro-1-naftol in $10 \%$ methanol in TBS and $0.03 \% \mathrm{H}_{2} \mathrm{O}_{2}$. The reaction was stopped in distilled water.

\section{Detection of glycoproteins with Con A}

After the transfer the blots were blocked in $0.1 \%$ Tween 20 in PBS at room temperature for $1 \mathrm{~h}$. Next, the membrane was incubated with biotinylated Con A $(10 \mu \mathrm{l} / \mathrm{ml}$ PBS, $\mathrm{pH}$ 7.4) for $1 \mathrm{~h}$ at room temperature and then the blots were washed $4 \times 5$ min in PBS and incubated with HRP $(20 \mu 1 / \mathrm{ml}$ PBS $)$ for $1 \mathrm{~h}$ at room temperature. After washing four times with PBS, the membrane was developed with 4-chloro-1-naftol as a substrate. The reaction was stopped in distilled water (Schallig et al., 1994).

\section{Results}

Electrophoresis of surface proteins in the fraction AP1 revealed 22 proteins with Mw's ranged from $126 \mathrm{kDa}$ to $27 \mathrm{kDa}$. In the fraction AP2 we identified 14 antigens ranged from 126 to $30 \mathrm{kDa}$ and the fraction AP3 showed 11 antigens ranged from 124 to $49 \mathrm{kDa}$. Detection of glyco- 
Table 1. Molecular weights of fractions of antigens recognized by serum Igs of infected mice

\begin{tabular}{|c|c|c|c|}
\hline $\begin{array}{l}\text { Extraction } \\
\text { buffer }\end{array}$ & $\begin{array}{l}\text { MW of protein fractions recognized by } \\
\text { IgG }\end{array}$ & $\begin{array}{l}\text { MW of protein fractions recognized by } \\
\text { IgA }\end{array}$ & $\begin{array}{l}\text { MW of protein fractions recognized by } \\
\text { IgM }\end{array}$ \\
\hline TBS & $\begin{array}{l}\sim 102,95,89, \underline{70}, \underline{65}, 60,58,50, \\
\underline{48}, 39,35,32\end{array}$ & $\sim 117,95,84, \underline{70}, 50,39,35$ & $\begin{array}{l}\sim 117,115,110, \underline{65}, 60, \underline{48,39}, \\
35\end{array}$ \\
\hline SDS & $\sim 110,106,91,75, \underline{70}, 61,55,46$ & $\sim 119,110, \underline{70}, 57$ & $\sim 110,106,91,75, \underline{70}, 55$ \\
\hline 2-Me & $\sim 108,91,75, \underline{70}, 58,52$ & $\sim 117,97$ & $\sim 91,58$ \\
\hline $\begin{array}{l}\mathrm{TBS}+\mathrm{NaCl}+ \\
\text { Triton } \mathrm{X}-100\end{array}$ & $\begin{array}{l}\sim 104,87,72,66, \underline{65}, 63,54,53, \\
50,47,41,37,32,31\end{array}$ & $\sim 87,79,72,69,67,66, \underline{65}, 44$ & $\begin{array}{l}\sim 112,80,79,69, \underline{65}, 63,47,44, \\
41,37\end{array}$ \\
\hline
\end{tabular}

MW - molecular weight [kDa]; TBS - Tris buffered saline, SDS - SDS containing buffer; 2-Me - 2-mercaptoethanol containing buffer

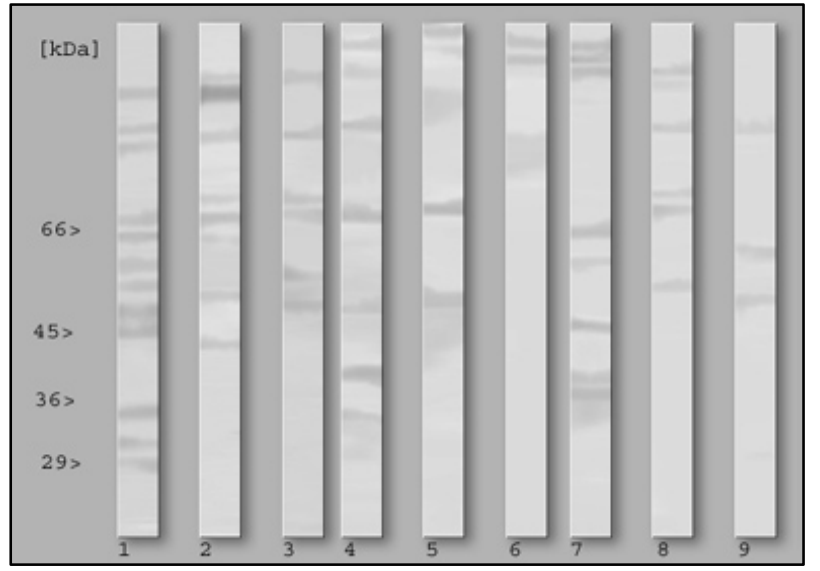

Fig.1. Western blots of $S$. obvelata surface extracts showing the polypeptides recognized by serum antibodies. Tracks: $1,2,3-\mathrm{AP} 1$, AP2, AP3 extracts recognized by serum IgG; 4, 5, 6- AP1, AP2, AP3 extracts recognized by serum IgA; 7, 8, 9- AP1, AP2, AP3 extracts recognized by serum $\operatorname{IgM}$

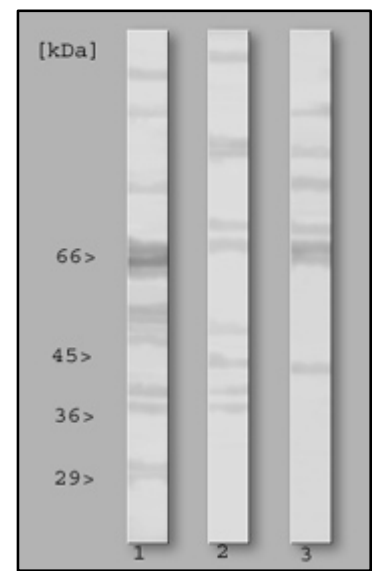

Fig.2. Western blots of $S$. obvelata somatic extract showing the polypeptides recognized by serum antibodies. Tracks: 1 - proteins recognized by serum IgG; 2 - proteins recognized by serum IgM; 3 - proteins recognized by serum IgA

Tab.2 Molecular weights of surface antigens recognized by mucosal Igs of infected mice

\begin{tabular}{lll}
\hline Extraction buffer & \multicolumn{1}{c}{ MW of protein fractions recognized by IgG } & \multicolumn{1}{c}{ MW of protein fractions recognized by IgA } \\
\hline TBS & $\sim 117,84, \underline{70}, \underline{65}, 58,50, \underline{48}, 44,39$ & $\sim 84, \underline{65}, 58,50, \underline{48}, 39$ \\
SDS & $\sim 91, \underline{70}, 61,52, \underline{48}$ & $\sim 52, \underline{48}$, \\
$2-\mathrm{Me}$ & $\sim 75, \underline{52}, 49$ & $\sim 82, \overline{75}, 49$ \\
\hline
\end{tabular}

MW - molecular weight [kDa]; TBS - Tris buffered saline, SDS- SDS containing buffer; 2-Me - 2-mercaptoethanol containing buffer

proteins using Con A revealed in TBS extract - 15 bands, SDS extract -12 and finally in 2-Me extract -5 bands. SDS-electrophoresis of AS extract showed 23 protein bands with molecular weights ranged from 90 to $27 \mathrm{kDa}$ as well as 15 bands of glycoproteins were detected.

The biotinylated surface proteins were electrophoresed, blotted and probed with serum and mucosa samples of infected and control mice. Numerous surface proteins of adult worms were recognized by antibodies of naturally infected mice (Tab.1, Fig.1). Out of 22 polypeptides found in TBS extract 12 were recognized by the serum $\mathrm{IgG}, 7$ by IgA and 8 polypeptides by IgM. Next fraction of SDS extract resolved 8 bands with $\operatorname{IgG}, 4$ with $\operatorname{IgA}$ and 6 with IgM. Within 2-Me fraction the reaction was observed with
4 bands for IgG, 2 for IgA and 3 bands for IgM. Western blot of AS extract showed reactions of 14 protein bands with serum IgG, 8 bands with $\operatorname{IgA}$ and 10 with $\operatorname{IgM}$ class (Tab.1, Fig. 2).

Mucosal IgG recognized 9 bands in AP1, 5 bands in AP2 and 3 bands in AP3 protein fraction bands. Mucosal IgA revealed reactions with 6 antigens of AP1 fraction, 2 of AP2 and 3 antigens of AP3 fraction respectively (Tab. 2, Fig. 3). In all tested serum and mucosa samples, immune response against surface and somatic antigens of $S$. obvelata was observed however fraction AP1 developed stronger reactions than fractions AP2 and AP3. Serum and mucosa samples obtained from control mice didn't recognize any protein extracts. 
Humoral immune response was elicited against all fractions of proteins both AS and AP. Surface protein of 70 $\mathrm{kDa}$ and somatic protein of $65 \mathrm{kDa}$ were recognized by serum $\operatorname{IgG}, \operatorname{IgA}$ and $\operatorname{IgM}$ classes. Moreover proteins of 70 $\mathrm{kDa}$ and $48 \mathrm{kDa}$ were recognized by mucosal antibodies.

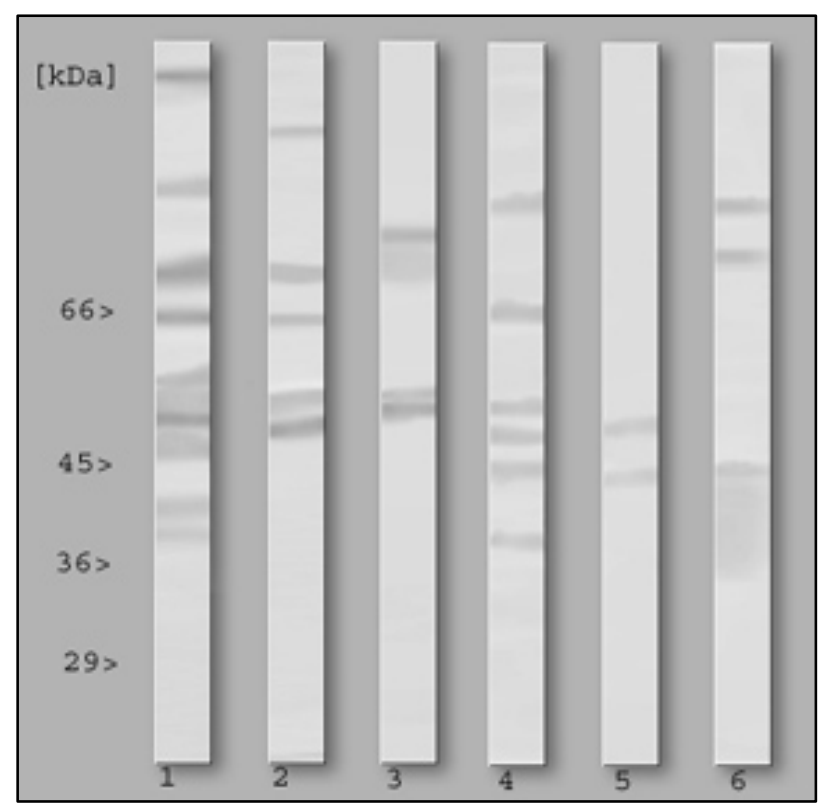

Fig.3. Western blots of $S$. obvelata surface extracts showing the polypeptides recognized by abomasal mucosa antibodies. Tracks: 1 , 2, 3 - AP1, AP2, AP3 extracts recognized by mucosal IgG; 4, 5, 6AP1, AP2, AP3 extracts recognized by mucosal IgA

\section{Discussion}

Many papers present the data on the parasites of farm and domestic animals, very important from the economical point of view. On the other hand, still little is known about naturally found parasites of laboratory animals e.g. pinworms, and their influence on experimental results. Pinworms commonly infecting laboratory mice include $S y$ phacia obvelata and Aspiculuris tetraptera. It has been reported (Jacobson \& Reed, 1974) that athymic (nu/nu) mice have increased susceptibility to pinworm infection. The prevalence of infection remains high even in well-managed animal colonies. While parasites are usually nonpathogenic, rectal prolapse, intussuspection, faecal impaction, rough hair coat and poor weight gain have been reported (McNair \& Timmons, 1977). There are a few reports documenting the effects of pinworms on research. Pinworms infection affecting mice physiologic functions have influenced experimental results. A significant reduction of activity of mice infected with $S$. obvelata was observed in behavioral studies (McNair \& Timmons, 1977). Wagner et al. (1988) reported clear growth differences between pinworm-free and pinworm-infected rats. Experimentally infected with $S$. muris animals grew slower than uninfected ones. It was reported that in laboratory rats infected with $S$. muris, despite of absence of apparent histopathological changes, intestinal transport of water and electrolytes is significantly decreased due to pinworm infection (Lübcke et al., 1992).

In pinworm infection as in many other helminthiases immunity is mostly humoral. Infection with $S$. obvelata induces a proliferation of $\mathrm{T}$ - and B-lymphocytes in spleen and lymph nodes and occasional germinal center formation (Beattie et al., 1981). For the first time investigations by Sato et al. (1995) have demonstrated Syphacia-specific antibodies (IgG) against $S$. obvelata somatic antigen in experimentally pinworm-infected mice (AKR/J strain).

In this study we demonstrate $\operatorname{IgG}, \operatorname{IgA}$ and $\operatorname{IgM}$ antibody isotypes against somatic and surface antigens during the course of natural infection with Syphacia obvelata in laboratory mice (BALB/c strain). Proteins were extracted and then analyzed on SDS-polyacrylamide gels. Polypeptides labelled with Con-A were also found in all extracts of adults of $S$. obvelata. We examined the local and systemic immune response against these antigens. The results of the examination of serum samples showed stronger immune response characterized by numerous immunogenic protein bands than with the mucosal antibodies, although intestinal mucosa is a habitat for $S$. obvelata. Surface polypeptides of AP1, AP2 and AP3 fractions with Mw's ranging from 119 to $32 \mathrm{kDa}$ detected by serum IgG, IgM and $\operatorname{IgA}$ were involved in eliciting systemic humoral immune response. Mucosal antibodies recognized less surface antigens with the molecular weights ranging from 117 to $39 \mathrm{kDa}$. In all tested serum and intestinal mucosa samples stronger antigenic reactions were observed among polypeptides of AP1 fraction than among polypeptides of AP2 and AP3 or AS fraction. Sato et al. (1995) observed on day 26 PI a dominant band of $65 \mathrm{kDa}$ in somatic extract. This protein was observed in surface fractions reacting with IgG and IgM classes and somatic fraction reacting with all examined isotypes of antibodies. Studies of Brett (1983) and Sato et al. (1995) found out that pinworm infection could activate host immune system by antibody production to nonparasitic antigenic stimulus.

Extraction of surface and somatic antigens of nematode $S$. obvelata and eliciting immune response in mice may have an application for the control of the infection in laboratory mice since many papers, e.g. by Shibahara (1999), Gilioli et al.(2000) or Pacoń and Piekarska (2004), inform about parasites in laboratory animal houses. Studies should be focused on the proteins of both extracts which show reactions with examined classes of antibodies and then identification of protective proteins would have an application value. In our paper, proteins of $\mathrm{Mw} \sim 70,65$ and $48 \mathrm{kDa}$ showed evident reaction with serum and mucosa antibodies of infected animals.

\section{Acknowledgements}

This work was supported by Polish Committee for Scientific Research (Grant KBN No. 3 P04C 094 25). 


\section{References}

BAUMANS, V. (1998): Environmental enrichment: practical applications. Proceedings of the $2^{\text {nd }}$ World Congress on Alternatives, Ultrecht 1998, 187 - 191

Bazzano, T., Restel, T. I., Pinto, R. M., Gomes, D. C. (2002): Patterns of infection with the nematodes Syphacia obvelata and Aspicularis tetraptera in conventionaly maintained laboratory mice. Mem. Inst. Oswaldo Cruz, Rio de Janeiro, 97: 1 - 5

BeAtTie, G. M., BAird, S. M., Lipsick, R. A., LANNON, R. A., KAPLON, N. O. (1981): Induction of T- and B-lymphocyte responses in antigenically stimulated athymic mice. Cancer Res., 41: 2322 - 2327

BRETT, S. J. (1983): Immunodepression in Giardia muris and Spironucleus muris infections in mice. Parasitology, 87: $507-515$

De Graaf, D. C., Berghen, P., Moens, L., De Marez, T. M., RAES, S., BLAXTER, M. L., Vercruysse, J. (1996): Isolation, characterization and immunolocalization of a globin-like antigen from Ostertagia ostertagi adults. Parasitology, 113: $63-69$

De Vos, T., DANell, G., Dick, T. A. (1992): Trichinella spiralis: dose dependence and kinetics of the mucosal immune responses in mice. Exp. Parasitol., 75: 99 - 111

DiCK, T. A., WriGHT, K. A. (1973): The ultrastructure of cuticle of the nematode Syphacia obvelata (Rudolphi, 1802). I. The body cuticle of larvae males, and females, and observation on its development. Can. J. Zool., 51: 187 $-196$

Gilioli, R., Andrade, L. A. G., Passos, L. A. C., Silva, F. A., Rodrigues, D. M., Guaraldo, A. M. A. (2000): Parasite survey in mouse and rat colonies of Brazilian laboratory animal houses kept under different sanitary barrier conditions. Arq. Bras. Med. Vet. Zootec., 52: 33 - 37

JACOBSON, R. H., REED, N. D. (1974): The thymus dependence of resistance to pinworm infection in mice. J. Parasitol., 60: 976 - 979

Keith, K. A., DunKan, M. C., Murray, M., Bairden, K., TAIT, A. (1990): Stage-specific cuticular proteins of Ostertagia circumcincta and Ostertagia ostertagi. Int. J. Parasitol., 20: 1037 - 1045

KOŁODYŃSKI, J., OKULEWICZ, A. (1998): Immunoprophylaxis in parasitology. Wiad. Parazytol., 44: $203-215$

LAEMMLI, U. K. (1970): Cleavage of structural proteins during the assembly of the head of bacteriophage T4. Nature, 227: $680-685$

LÜBCKe, R., Hutchenson, F. A. R., Barbezat, G. O. (1992): Impaired intestinal electrolyte transport in rats infested with the common parasite Syphacia muris. Dig. Dis.
Sci., 37: $60-64$

MCNAIR, D. M., Timmons, E. H. (1977): Effects of Aspiculuris tetraptera and Syphacia obvelata on exploratory behavior of an inbred mouse strain. Lab. Anim. Sci., 27: 38 42

Okulewicz, A., Perec, A. (2003): Parasite infections in laboratory mice colonies. Polish J. Vet. Sci, 6: $51-53$

PACOŃ, J., PIEKARSKA, J. (2004): Mice parasites in selected colonies of laboratory animal houses. Wiad. Parazytol., 50: $93-94$

PANTER, H. C. (1969): Studies on host-parasite relationships: Syphacia obvelata in the mouse. J. Parasitol., 55: 74 $-78$

Pinto, R. M., Vicente, J. J., Noronha, D., Goncalves, L., GoMES, D. C. (1994): Helminth parasites of conventionally maintained laboratory mice. Mem. Inst. Oswaldo Cruz, Rio de Janeiro, 89: 33 - 40

Pinto, R. M., Goncalves, L., Noronha, D., Gomes, D. C. (2001): Worm burdens in outbred and inbred laboratory rats with morphometric data on Syphacia muris (Yamaguti 1935) Yamaguti, 1941 (Nematoda, Oxyuroidea). Mem. Inst. Oswaldo Cruz, Rio de Janeiro, 96: 133 - 136

Sato, Y., OoI Monaka, O. K., Nonaka, N., OKU, Y., KAMIYA, M. (1995): Antibody production in Syphacia obvelata infected mice. J. Parasitol., 81: 559 - 562

Schallig, H. D. F. H., Van Leeuwen, M. A. W. (1994): Immune responses of Texel sheep to excretory/secretory products of helminth parasites: effects on host immune responses. Parasitology, 96: 123 - 166

SHIBAHARA, T. (1999): Necessity of reexamining the pathogenicity and elimination of parasites in rats and mice. Microbial status and genetic evaluation of mice and rats. Proc. 1999 US/Japan Conference

TAFFS, L. F. (1976): Pinworms infections in laboratory rodents: A review. Lab. Anim., 10: 1 - 13

Towbin, H., Stacklin, T., Gordon, J. (1979): Electrophoretic transfer of protein from polyacrylamide gels to nitrocellulose sheets: procedure and some applications. Proc. Natl. Acad. Sci. U.S.A., 76: 4350 - 4354

WAGNER, M. (1988): The effect of infection with the pinworm (Syphacia muris) on rat growth. Lab. Anim. Sci., 38: $476-478$

Wędrychowicz, H., Homles, P. H., TAIT, A. (1994): Surface antigens of exsheated infective larvae of Ostertagia circumcincta. Acta Parasitol., 39: 162 - 169

WĘDRYCHOWICZ, H. (1997): Surface proteins of nematodes and thier role in host-parasite relationship. Med. Wet., 53: $566-569$ 